\title{
Successful aging - the nurse - aged person interaction process in primary health care
}

\section{Envelhecimento bem-sucedido - Processo de interação enfermeiro-pessoa idosa em cuidados de saúde primários}

\author{
Maria João Soares Rodrigues de Sousa Fernandes \\ Escola Superior de Saúde Ribeiro Sanches - ERISA, Rua do Telhal aos Olivais, no 8-8 1900-693Lisboa, Portugal \\ CBIOS - Centro de Investigação em Ciências e Tecnologias da Saúde, Grupo Lusófona, Campo Grande, 376, 1749 - 024 Lisboa \\ Email: maria.fernandes@erisa.pt
}

\begin{abstract}
With the aging population and the natural increase of nursing care within gerontology, there is increasing interest in how the nurse interacts with the aged person and utilizes their role to protect and promote successful aging behaviors. The goal lies in understanding the nurse-aged person interaction process. This is a naturalistic study of qualitative paradigm and inductive reasoning, developed in the context of primary health care. We observed the interaction process between nurse and older person in various Health Centers and Day/Socializing Centers and supplemented the information with an interview. The grounded theory analysis method of Corbin \& Strauss was used, which provides the triangulation of data and uses theoretical sampling.

The nurse-aged person interaction is established in a joint process of recreation of the gerontologic care predisposing, fostering and strengthening knowledge about the essence of life. The elderly person who is the object of nurse care, builds their lived experience by aiming towards integrity, establishing individual and social interaction and enhancing experiences. From this whole interaction process, a central concept emerges: clarification of the aged person's lived experience.
\end{abstract}

Keywords: Successful aging, nurse, aged person.

\section{Resumo}

Com o envelhecimento demográfico e o natural aumento dos cuidados de enfermagem no âmbito gerontológico surge o interesse em responder como é que o enfermeiro interage com a pessoa idosa para que esta utilize a sua essência evidenciando comportamentos protetores e promotores de envelhecimento bem-sucedido? E ao objetivo: compreender o processo da interação enfermeiro-pessoa idosa que conduz à utilização de comportamentos protetores e promotores de envelhecimento bem-sucedido.

Trata-se de um estudo naturalista de paradigma qualitativo, de pensamento indutivo, desenvolvido num contexto de cuidados de saúde primários. Observámos o processo de interação entre enfermeiro-pessoa idosa num Agrupamento de Centros de Saúde e em Centros de Dia/Convívio e completámos a informação com entrevista. Utilizámos o método de análise grounded theory segundo Corbin \& Strauss ${ }^{[1]}$ que prevê a triangulação de dados bem como o recurso a amostragem teórica.

A interação enfermeiro-pessoa idosa estabelece-se num processo conjunto de recriação do cuidado gerontológico predispondo, favorecendo e reforçando o conhecimento sobre o cerne da vida. A pessoa idosa objeto de cuidados do enfermeiro vai construindo o seu vivido caminhando para a integridade, estabelecendo interação individual e social e intensificando vivências. De todo este processo de interação emerge o conceito central: clarificação do vivido.

Palavras-chave: Envelhecimento bem-sucedido, enfermeiro, pessoa-idosa. 


\section{Introduction}

Political, social and health organizations have accompanied the demographic shift, readjusting their action plans to the new demands of citizens ${ }^{[2,3]}$. The much discussed and demonstrated increasing aging population ${ }^{[4]}$ makes us think about nursing care that might effectively respond to the real needs of longer experienced longevity.

The fact that people are living longer has led to disease, multiple illnesses, addictions and disabilities in the older adult, but it has also implied successive hospitalizations and negative experiences in nursing homes ${ }^{[5,6,7]}$. However, in primary health care, the promotion of successful aging is also valued ${ }^{[8,9,10]}$.

Nursing accompanies the person in their life process specially when their health is interrupted, but it also needs to be prepared to influence the aged person in obtaining favorable results regarding adaptation to changes in environment as time goes by. Ferrario, Freeman, Nellet and Scheel [11] Gavan ${ }^{[12]}$ and Sikora ${ }^{[13]}$ underline that it is necessary to have a positive view of the aging process for nurses and nursing students who are interested in dedicating themselves to the gerontologic area. Concomitantly, when professionals integrate positive concepts relating to the aging process, they get involved more easily with the aged person with the aim of triggering their capacity to develop a successful aging process ${ }^{[14]}$.

In the light of the recognized conceptual ambiguity of successful aging, we accepted the definition: "favorable outcome perceived by the individual, and its ability to cope or adapt to the cumulative changes associated with the passage of time, while experiencing a sense of meaning or purpose in life"[10].

We set out to understand the interaction process between the nurse and the aged person that leads to the protecting and promoting behaviors of successful aging.

\section{Materials and Methods}

We selected a naturalistic study of qualitative paradigm, explanation and of inductive reasoning, which was developed in the context of primary health care. The interaction process between nurse and aged person was observed in various Health Centers and Day/Socializing Centers and supplemented with information obtained through an interview. Table 1 presents the global work-

\section{Introdução}

Organizações políticas, sociais e de saúde têm acompanhado a mudança demográfica reajustando os seus planos de ação às novas exigências dos cidadãos ${ }^{[2,3]}$. $\mathrm{O}$ tão evidenciado e debatido aumento da população idosa ${ }^{[4]}$ confere-nos pensar em cuidados de enfermagem que respondam com eficácia às necessidades reais de quem fruiu maior longevidade.

$\mathrm{O}$ facto de as pessoas viverem mais anos tem feito sobressair os fenómenos doença, múltiplas doenças, dependências e incapacidades instalados no adulto idoso, bem como sucessivas hospitalizações e experiências negativas em lares ${ }^{[5,6,7]}$. Mas, em cuidados de saúde primários, valorizamos igualmente a promoção do envelhecimento bem-sucedido ${ }^{[8,9,10]}$.

A enfermagem acompanha a pessoa na reposta ao seu processo de vida em situação de interrupção de saúde, mas carece igualmente de estar preparada para influenciar a pessoa idosa na obtenção de resultados favoráveis determinados pela forma como se adapta às modificações do meio decorrentes da passagem do tempo. Daí Ferrario, Freeman, Nellet e Scheel ${ }^{[11]}$, Gavan ${ }^{[12]}$ e Sikora ${ }^{[13]}$ afirmarem que é necessário ter uma visão positiva do processo de envelhecimento para que enfermeiros e estudantes de enfermagem se interessem por se dedicar à área gerontológica. Concomitantemente, quando profissionais integram conceitos positivos face ao processo de envelhecimento, com maior facilidade intervêm junto da pessoa idosa com a intenção de lhe desencadear o aumento das suas capacidades para desenvolver um envelhecimento bem-sucedido ${ }^{[14]}$.

Pela reconhecida nebulosidade conceitual de envelhecimento bem-sucedido aceitámos a definição: "resultado favorável percecionado pelo indivíduo e a sua habilidade de responder ou se adaptar às mudanças cumulativas associadas à passagem do tempo enquanto experiencia o significado e sentido na vida" (p. 36) [10].

Propusemo-nos assim compreender o processo da interação enfermeiro-pessoa idosa que conduz à utilização de comportamentos protetores e promotores de envelhecimento bem-sucedido.

\section{Materiais e métodos}

Selecionámos um estudo naturalista, de paradigma qualitativo, explicativo, de pensamento indutivo, desenvolvido num contexto de cuidados de saúde primários. Observámos o processo de interação entre enfermeiro-pessoa idosa num Agrupamento de Centros de Saúde (ACES) e em Centros de Dia/Convívio e completámos a informação com entrevista. Na tabela 1, apresentamos 
ing field developed by describing the different data collections distributed across various time intervals.

By using the grounded theory analysis method by Corbin \& Strauss ${ }^{[1]}$ data triangulation and theoretical sampling was performed.

The permanent data comparative analysis took place simultaneously with its systematic collection. The process started by open codification, reached axial codification, then selective, returning to the open codification whenever new data were obtained. Words and text segments were dissociated, carefully examined and compared in order to capture similarities and differences. The constant comparison of data allowed for the identification of concepts and their properties and dimensions. We tried to answer the questions "how, what, where, when and why", in order to describe the conditions, circumstances or situations that form the structure of the nurse-aged person interaction. The description was extended to actions/interactions, checking the strategies that people adopt in their lived relationships and the consequences or results of the whole process. Data treatment and analysis was performed with the tool NNivo7 ${ }^{[15]}$.

Internal validation was performed by the participants and external validation by experts. The external judges not only certified the stability of the emerged categorization but also confirmed consistency in the theoretical explanation of the studied phenomenon.

The protocol for ethical procedures were fully complied with by providing detailed explanation of the study to participants and by obtaining consent and approval from the leaders of the organizations where the study took place.

\section{Results}

Comparative analysis of data revealed two major components: the recreation of the gerontological care that stemmed from categories, predisposing, fostering and strengthening the knowledge; and the construction of the lived experience that emerged from the categories, aiming for integrity, establishing individual and social interaction and enhancing experiences. Of all the components and respective categories emerges a central concept - the clarification of the lived experience. Figure 1 resumes this nurse-aged person interaction process. a totalidade do trabalho de campo desenvolvido, descrevendo as diferentes recolhas de dados, distribuídas pelos vários intervalos de tempo.

Ao utilizarmos o método de análise grounded theory segundo Corbin \& Strauss ${ }^{[1]}$ efetuámos triangulação de dados bem como recorremos a amostragem teórica.

A constante análise comparativa de dados decorreu em simultâneo com a sua recolha sistemática. Começámos pela codificação aberta, chegámos à codificação axial, depois seletiva, retomando a codificação aberta sempre que obtínhamos novos dados. Dissociaram-se palavras, segmentos de texto, os quais foram examinados atentamente e comparados entre si com o fim de se captarem similaridades e diferenças. A comparação constante de dados permitiu a identificação de conceitos, as suas propriedades e dimensões. Procurámos responder às questões: como, o quê, onde, quando e porquê, de forma a descrevermos as condições, circunstâncias ou situações que formam a estrutura da interação enfermeiro-pessoa idosa. A descrição estendeu-se às ações/interações, verificando as estratégias que as pessoas adotam no seu percurso vivido, nas suas relações e as consequências ou resultados de todo o processo.

O tratamento e análise de dados foram efectuados com a ferramenta NNivo ${ }^{[15]}$.

A validação interna foi realizada pelos participantes e a externa por peritos. Os juízes externos não só certificaram a estabilidade da categorização emergida como confirmaram a consistência presente na explicação teórica do fenómeno estudado.

Cumprimos o protocolo de procedimentos éticos com a explicação do estudo aos participantes, da obtenção do seu consentimento, bem como através da autorização dos líderes da Organizações onde decorreu o trabalho de campo.

\section{Resultados}

Da análise de comparação de dados emergiram duas grandes componentes: a recriação do cuidado gerontológico que adveio das categorias, predispondo, favorecendo e reforçando o conhecimento; e a construção do vivido que surgiu das categorias caminhando para a integridade, estabelecendo interação individual e social e intensificando vivências. De todas as componentes e respetivas categorias emerge o conceito central: clarificação do vivido. A figura 1 facilita a compreensão do processo de interação enfermeiro-pessoa idosa. 


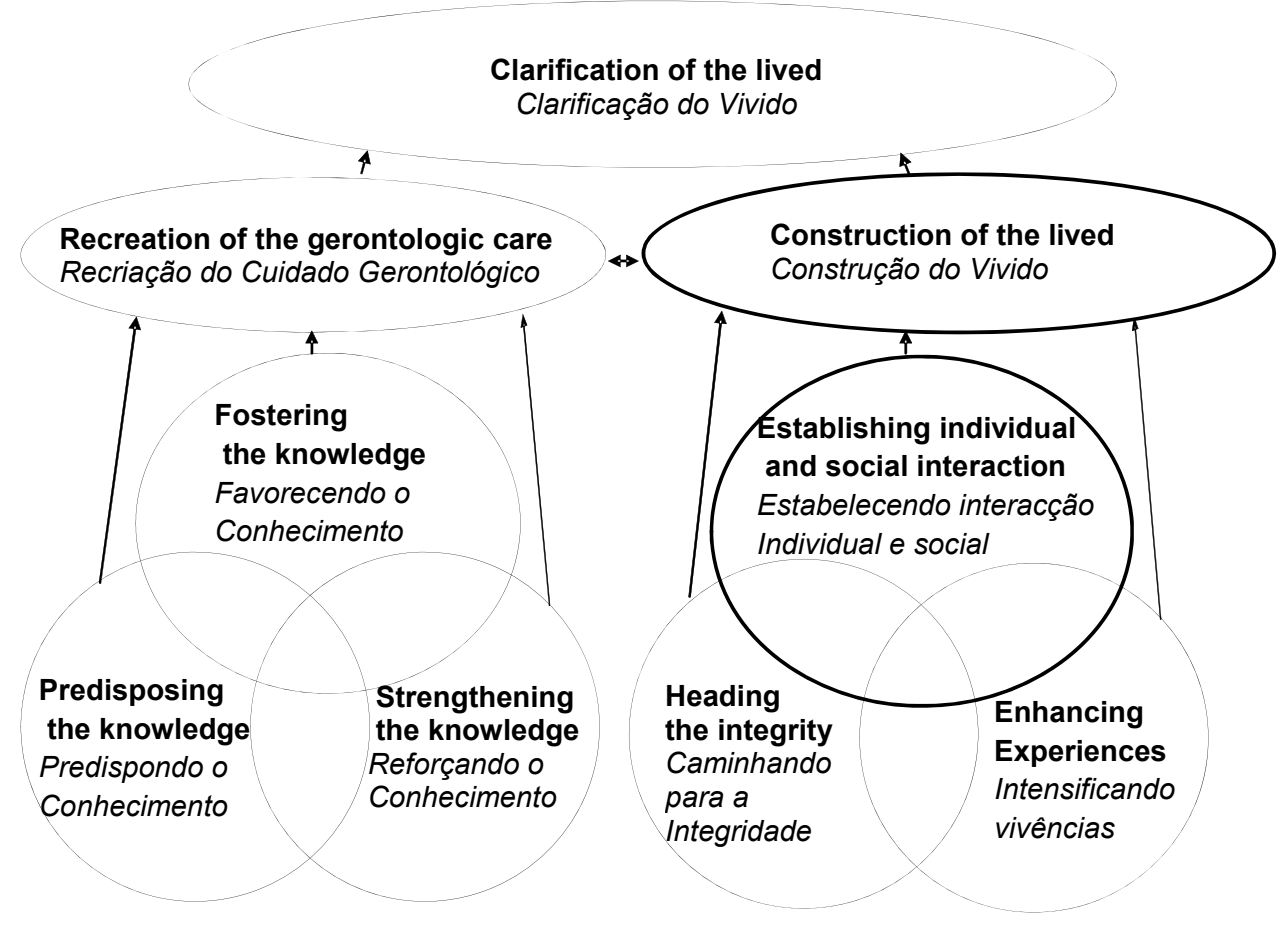

Figure 1 - Nurse-elderly person interaction process

Figura 1 - Processo de interação enfermeiro-pessoa idosa

\section{The recreation of the gerontological care}

In the category predisposing knowledge, the nurseaged person interaction is triggered because while nurses want to develop new nursing activities, the aged person wants to acquire new knowledge. Over time and in varied spaces this interaction keeps building in an accessible form, with planned, scheduled and publicized activities through its presentation. The site of action will be available for the meeting and both the preparation of the environment and equipment are valued, as well as the certification of the procedure. There is a special attention to the reception process. It is important to note that the nurse has knowledge of the client through evaluations including clinical, physical, and physical activity. There is a sense of achievement of objectives. The individualization of care is obvious, as is its continuity and negotiation. All this interactive process results in health promotion. "... we do promote health and aging with quality"(efenfB).

The category fostering knowledge is triggered by the search for well-being. The action takes place on time, with due attention, time availability, action control, conversation, information selection, and facilitating

\section{Recriação do cuidado gerontológico}

$\mathrm{Na}$ categoria predispondo o conhecimento a interação enfermeiro-pessoa idosa é desencadeada porque os enfermeiros querem desenvolver novas atividades de enfermagem e a pessoa idosa quer adquirir novos saberes. Ao longo do tempo e em espaços variados a interação vai evoluindo duma forma acessível, com atividades programadas, calendarizadas e divulgadas através da sua apresentação. O local da ação vai sendo disponibilizado para o encontro e são valorizadas tanto a preparação do ambiente e equipamento, como a certificação do procedimento. Há uma atenção especial com o acolhimento. Destaca-se, o facto de o enfermeiro ter conhecimento do cliente através das avaliações que executa: clínica, física e atividade física. Há um sentido de cumprimento de objetivos. Está patente a individualização dos cuidados, a sua continuidade e negociação. Todo este processo interativo tem como consequência a promoção da saúde. “... a gente faz as promoções, trabalha a promoção da saúde do envelhecimento com qualidade" (efenfB)

A categoria favorecendo o conhecimento é desencadeada pela procura do bem-estar. A ação decorre com pontualidade, atenção, disponibilidade de tempo, controlo 
learning through sensory stimulation and knowledge with the use of visual media and registration documents. People having a sense of belonging also favors the process. People develop a harmonious relationship through warmth, greeting and smiling. In this relationship, an integrating state of mind favorable to this process is created because it incorporates affection, tranquility, softness, enthusiasm, emotion, empathy, extraversion and joy. Collaborative manifestations are identified, both internal and external in the performance of activities. The farewell is also favorable because it presupposes a single interval until the next meeting. Consequently people find solutions "(...) I prefer not to look. I keep moving and walking away." (efpiA) and problem resolution "People arrive with problems and we have to try to find a proper solution(...)" (efenfA).

Since those involved clearly need information, they keep strengthening knowledge. The impact of the nurseaged person interaction process becomes clearer as experiences are accumulated, as the family gets involved, with the active participation of all those involved, with the recognition of nursing and with the positive evaluation of the actions and appreciation of the results. Consequently, the older person gains new knowledge, new habits and skills which integrate the maintenance of independence into their lives, "[Some clients already have] self-monitoring of blood glucose.”(OpCDSJP23-4-08).

\section{Construction of the lived experienced}

The older person who turns to the nurse for information and who seeks their own well-being while aiming for integrity, surely had a childhood which facilitated this development and which determined lifelong learning, helping others while remembering the past. They look to the future with a positive attitude, advocating a life with quality and preventing events that might inhibit or limit it. They are aware of their own empowerment. They take care of their health, watching, protecting and appreciating it. They recognize the advantages of growing old: years achieved, memories, learning, wisdom, and dignity.

The aged person also keeps establishing individual and social interaction through adaptations to change, offsetting the losses, using compensatory ways and social support such as domestic support. The older person keeps highlighting good functioning, confronting their individuality and expressing characteristics that are intrinsic to them such as tolerance, safety, determination, da ação, preocupação, conversação, seleção da informação, facilitando a aprendizagem através da estimulação sensitiva e do conhecimento com a utilização de meios visuais e documentos de registo. Também é favorável o facto de as pessoas terem sentido de pertença. As pessoas desenvolvem uma relação harmoniosa através de cordialidade, saudação e sorriso. Nesta relação capta-se um estado de espírito integrador deste processo favorável porque incorpora afeto, tranquilidade, suavidade, entusiasmo emotividade, empatia, extroversão e alegria. Identificam-se manifestações colaborativas, quer internas quer externas na realização das atividades. A despedida também é favorável porque pressupõe um simples intervalo até ao próximo encontro. Consequentemente as pessoas vão ao encontro de soluções "(...) prefiro não olhar. Vou descendo e toca a andar e despacho-me." (efpiA) e da resolução de problemas "As pessoas vêm com problemas e nós temos que tentar resolvê-los (...)” (efenfA).

Com a evidente necessidade de informação sentida pelos atores percebemos que estes vão reforçando o conhecimento. À medida que as experiências vão sendo adicionadas, a família envolvida, com a participação ativa dos atores, o reconhecimento da enfermagem, a avaliação positiva das ações e valorizando os resultados, vai-se revelando o impacto da interação enfermeiro-pessoa idosa. Consequentemente a pessoa idosa denota novos conhecimentos, novos hábitos e skills os quais integram a manutenção da independência "[alguns clientes já têm] autocontrolo da glicemia." (opCDSJP23-4-08).

\section{Construção do vivido}

A pessoa idosa que procura o enfermeiro porque sente necessidade de informação e porque vai procurando bem-estar enquanto vai caminhando para a integridade, teve um desenvolvimento infantil facilitador dessa evolução, foi aprendendo ao longo da vida, vai lembrando o passado e ajudando outros. Distingue-se que projeta o seu futuro com uma atitude positiva, preconizando uma vida com qualidade, prevenindo acontecimentos que a inibam ou a limitem. Está consciente do empowerment que detém. Mantém a saúde vigiando-a, protegendo-a e valorizando-a. Reconhece ganhos provenientes do envelhecimento realçando: anos alcançados, recordações, aprendizagem, sabedoria e dignidade.

Também vai estabelecendo interação individual e social através de adaptação à mudança, compensando perdas, utilizando meios compensatórios e suporte social como é o caso do apoio doméstico. A pessoa idosa vai destacando bom funcionamento, confrontando-se com a sua individualidade e manifestando característi- 
team spirit and a positive relationship with their own image.

As in the past, their life experiences are still being intensified. In their work context throughout their professional life, by establishing the work-employment relationship, allowing for constant evaluation and showing an intense way of enjoying beauty expressed by wonder.

It is also evident that the person passes on their cultural testimony, participating in social - historical activities. Throughout the person's life their family ties were fortified. They experienced the nuclear family, valued their marital relationship, supported their family, sought family closeness and cautioned against preference for younger people. It is a person who manages their own everyday life, who does their shopping and housework and who demonstrates spirituality through verbal expression.

In all the categories that form the construction of the lived experience, the older person seeks, in consequence, to design their future by promoting a positive attitude: “(...) I have hope for tomorrow." (efpiD) and living cautiously: “(...) I climb the ladder but (...) I don't look down because (...) I know that already get a bit off site " (efpiA). They express recognition of their own empowerment: "I like to see (...) Speak up because I would like to hear. (...) Wants to know the evaluation results "(opCDSJP20-5-08). They look after their own health: "Recommended to go to the Health Center (...)" (opCDSJE27-5-08), they protect their health: "(...) I put my feet in water and scrape them. ... To protect my feet, (...) "(opCDSJE27-5-08), and value it: "With bandage because it doesn't macerate the skin ..." (opCDSJE27-5-08). In addition, they recognize the advantages of age: "Aging is also a status"(EvpiN), memories: "Satisfied with memories from the past "(eipiHCSJP27-5-08), learning: "What they possess they have already learned it” (efenfB), wisdom: “(...) wisdom keeps being gained." (EipiC) and dignity: “(...) ageing with dignity is nice." (EipiA).

\section{Clarification of the lived experience}

We realize that we are dealing with a nurse who clearly understands the client's request for explanations, which in this case involves an old person seeking to live life transparently free from doubts. During this interaction people want to understand or make comprehensible what is happening during the continuum of life, where it concerns themselves as well as the surrounding environment. People seek to clarify, make intelligible, cas que lhe estão intrínsecas tais como: ter capacidade de tolerância, segurança, determinação, espírito de grupo e relação positiva com a imagem que tem de si. A pessoa idosa foi e vai também intensificando vivências. Foi produzindo no seu contexto de trabalho ao longo do seu percurso laboral, estabelece relação com o trabalho-emprego, vai avaliando o quotidiano, manifesta uma forma intensa de apreciar o belo que expressa por maravilhamento. Percebe-se também que a pessoa vai passando testemunho cultural e participando em atividade sócio históricas. Ao longo da vida foi fortificando laços familiares, transitando para a vida nuclear, valorizando a relação conjugal, apoiando familiares, procurando proximidade familiar e acautelando a preferência dos outros pelos mais novos. É uma pessoa que gere o quotidiano efetuando as suas compras e a lida doméstica. Evidencia igualmente espiritualidade através das suas expressões verbais.

Em todas as categorias que fazem emergir a construção do vivido, a pessoa idosa procura consequentemente projetar o seu futuro fomentando atitude positiva "(...) tenho esperança do dia de amanhã." (efpiD) e vivendo cautelosamente "(...) subo o escadote mas (...) não olho para baixo porque (...) eu já sei que fico um bocadinho off site" (efpiA), denota reconhecer o seu empowerment "Eu gosto de ver (...) Fale alto porque eu gosto de ouvir. (...) Quer ter conhecimento dos resultados da avaliação" (opCDSJP20-5-08), mantem a saúde vigiando-a "Recomendou que fosse ao Centro de Saúde (...)" (opCDSJE27-5-08), protegendo-a "(...)ponho os pés de molho e raspo os pés. ...para proteger os pés, (...)" (opCDSJE27-5-08) e valorizando-a "Com adesivo não porque macera a pele..." (opCDSJE27-5-08), para além de reconhecer ganhos no envelhecimento como anos de vida "mais idade também é um status" (evpiN), memórias "Satisfeito com as recordações do passado" (eipiHCSJP27-5-08), aprendizagem "O que eles têm já aprenderam" (efenfB), sabedoria "(...)A sabedoria que se vai ganhando." (eipiC) e dignidade "(...) envelhecer com dignidade é bonito." (eipiA).

\section{Clarificação do vivido}

Percebemos que estamos perante um enfermeiro que torna clara a explicação solicitada pelo cliente e por uma pessoa idosa que procura viver a vida de forma transparente, sem dúvidas. Durante a interação as pessoas querem compreender ou fazer compreender o que se passa no contínuo da vida: com elas próprias e com o meio que as rodeia e com o qual se relacionam. As pessoas procuram aclarar, tornar inteligível, interpretar o 
and interpret what is happening. They want to clarify what they still do not completely know. Restlessness is felt in the search for knowledge. Both nurses and the aged actively participate in this process. This is why the central concept clarification of the lived experienced emerged.

Clarification of the lived experienced arises when one realizes that all action stems from the person's own need to clarify their own path in life. This concept emerges directly from actions involving: explanation, questioning, exemplification, description, statement, confirmation, validation, decoding, searching, capturing, clarification and information. Throughout the study and in any context and space where the interaction between nurse and aged person exists, clarification of the lived experienced is guided by the search for knowledge and understanding.

The entire nurse-aged person interactive process is imbued by this clarifying condition of events that incorporate life and that its own internal validation predicts: "they are trying to understand better what we try to transmit. And that is to clarify "(efB:3).

\section{Discussion}

Regarding the reconstruction of the gerontologic care dimension, we shall start by highlighting the analogy between a positive attitude towards life of the studied elements in the social group and the paradigmatic ideas of Pender, Murdaugh and Parsons ${ }^{[15]}$. These authors stress the proactive health promotion standard, convinced that it is much more important to invest in the well-being and prevention of disease when possible, than to have to live with it ${ }^{[16]}$. Health promotion is, in fact, emphasized due to this positive attitude. Although Flood ${ }^{[9,10]}$ expressed himself in a different way, he did not move away from this health promotion idea and accepted this definition of successful aging: "favorable outcome perceived by the individual and its ability to respond or adapt to cumulative changes associated with the passage of time while experiencing the meaning in life". It is interesting to note the similarities with the Gestsdottir and Lerner theory ${ }^{[17]}$ in which, by regulating the adaptive development, the person has the purpose to show a positive attitude when searching for well-being over time.

Regarding the favoring knowledge category, a whole educational process is revealed and reflected in the foreseen results. Maybe we can accept the parallelism with the search for wisdom that in a way is attributed to an older, more mature person ${ }^{[18]}$. que se passa. Querem esclarecer o que ainda não sabem na totalidade. Sente-se uma inquietude na procura do conhecimento. Tanto, enfermeiras como pessoas idosas participam ativamente neste processo. Daí ter emergido como conceito central clarificação do vivido.

Clarificação do vivido surge quando se percebe que toda a ação decorre da necessidade que a pessoa sente em tornar claro o seu percurso de vida. Este conceito emerge diretamente das ações que envolvem: explicação, questionamento, exemplificação, esclarecimento, descrição, indicação, confirmação, validação, descodificação, procura, captação, clarificação e informação. Ao longo do estudo e em qualquer contexto e espaço onde se verifica interação enfermeiro-pessoa idosa, a clarificação do vivido é norteada pela procura do conhecer e compreender.

Todo o processo interativo, enfermeiro-pessoa idosa está imbuído desta condição clarificadora dos acontecimentos que incorporam a vida e a própria validação interna o prediz: "eles estão procurando compreender melhor aquilo que nós tentamos passar. É clarificar mesmo" (efB:3).

\section{Discussão}

$\mathrm{Na}$ dimensão reconstrução do cuidado gerontológico começamos por destacar a analogia entre a atitude positiva face à vida dos elementos que integram o grupo social estudado e a ideia paradigmática das teóricas Pender, Murdaugh e Parsons ${ }^{[16]}$. As autoras incrementam o padrão pró-ativo de promoção da saúde convictas de ser muito mais importante investir-se no bem-estar e na prevenção da doença, não deixando que esta aconteça, quando é evitável o ter que se conviver com ela [17]. É de facto salientada a promoção da saúde como consequência desta atitude positiva. Apesar de diferente, Flood ${ }^{[9,10]}$ não se afastou desta ideia de promoção da saúde ao aceitar para definição de envelhecimento bem-sucedido: resultado favorável percecionado pelo indivíduo e a sua habilidade de responder ou se adaptar às mudanças cumulativas associadas à passagem do tempo enquanto experiencia o significado e sentido na vida. Interessante a similitude com a teoria explicada por Gestsdottir e Lerner ${ }^{[18]}$ em que através da regulação do desenvolvimento adaptativo a pessoa tem o propósito de evidenciar uma postura positiva quando procura bem-estar ao longo do tempo.

$\mathrm{Na}$ categoria favorecendo o conhecimento vai-se denotando todo um processo educacional que se repercute nos resultados desejados. Talvez possamos consagrar o paralelismo com a procura da sabedoria que de certo 
The Spanish community modified its lifestyle by joining the multimedia program "live with vitality" by Fernandez-Ballesteros, Caprara and Garcia ${ }^{[19]}$. This involved increased exercise, a diversified diet and increased life satisfaction. Study participants also added experiences including new foods to their normal diet, exercised and actively participated in the social group that satisfies the lived experience.

Regarding the construction of the lived experience dimension, it is clear that the person is aiming towards integrity. Integrity is the part of the human condition that falls under self-knowledge and knowledge about the world ${ }^{[20]}$. Integrity is meant to promote contact with the self, with the world, with things and especially with people. "It is a tactile and tangible path to live" [20]. When one is evolving towards integrity, the ability to sense signals and sounds is identified; there is a request to pay attention to the life details in which everything seems straightforward, simple, and equally difficult. Integrity allows for contact with the self and the reality of the surrounding world. During old age, the 8th stage of life, all meetings have a special meaning. Integrity allows old age to be experienced in its natural and fully pleasant form.

Reflecting on the individual and social interaction category, we realized that the aged person interacts with themself through consciousness (the individual's perception about their own condition). They realize when acting, and sense their own action ${ }^{[21,22]}$. In this sense, the older person perceives the relationship established with themself. They also participate and interact with the society in which they operate. They respond to requests made by people within the community ${ }^{[23,25,26]}$. As time goes by and experiences accumulate, the aged person shows their origin differences, emphasizing skills or limitations determined by genetics dyad and environment. A complete search process related to themself as an actor in the surrounding environment develops. This adapting to change proves the individual and social interaction and compensates losses using compensating methods and social support. It is similar to that explained by the selection, optimization and compensation model (SOC) ${ }^{[40,41]}$ where the person analyzes and evaluates their internal and external resources in which they define achievable goals, maximizing the use of their potentials at their disposal in the surrounding environment and minimizing the effects of their deficits or disabilities. Selection, optimization and compensation is a strategic process under which people adopt a relationship with the environment by managing their internal and external resources in a way that allows them to experience successful development ${ }^{[27]}$. Old age should be lived by sharing the earth with all others. There is an modo vai-se atribuindo à pessoa com mais idade e mais maturidade ${ }^{[19]}$.

A comunidade espanhola ao aderir ao programa multimédia "viver com vitalidade" de Fernández-Ballesteros, Caprara e García ${ }^{[20]}$ modificou os seus estilos de vida: aumentou o exercício físico, diversificou a dieta e aumentou a satisfação com a vida. Os participantes do estudo também acrescentaram experiências entre as quais: a adição de novos alimentos na sua dieta, o exercício e têm uma participação ativa no grupo social que lhes satisfaz o vivido.

$\mathrm{Na}$ dimensão construção do vivido salienta-se a integridade para a qual a pessoa vai caminhando. A integridade é a parte da condição humana que se insere no conhecimento sobre si mesmo e sobre o mundo [21]. Integridade tem a função de promover contacto com o self, com o mundo, com as coisas e principalmente com as pessoas. "É um caminho táctil e tangível para viver" [22]. Quando se está a evoluir para a integridade identifica-se a capacidade para sentir sinais e sons, há uma solicitação para se estar atento aos detalhes de uma vida em que tudo parece direto, simples e igualmente difícil. A integridade permite o contacto com a própria pessoa e a realidade do mundo que a envolve. Durante a velhice ou $8^{\circ}$ estádio da vida, todos os encontros têm um significado especial. A integridade permite que a velhice seja vivida de uma forma natural e cheia de prazeres. Refletindo sobre a categoria estabelecendo interação individual e social percebemos que a pessoa idosa interage consigo própria através da consciência (perceção que o sujeito tem do seu próprio estado). Ela percebe quando age e sente o seu próprio ato ${ }^{[22,23]}$. Neste sentido, a pessoa idosa tem perceção da relação que estabelece consigo. Igualmente interage e participa com a sociedade em que se insere. Responde às solicitações que lhe são efetuadas pelas pessoas da comunidade onde vive ${ }^{[24,26,27]}$. Com a passagem dos anos e a acumulação de experiências, os idosos evidenciam as suas diferenças originárias, acentuando as competências ou limitações que a díade genética e ambiente vão manifestando. Desenvolve-se todo um processo de procura da experiência face a si próprio e enquanto ator no seu ambiente. Por isso esta interação individual e social ser comprovada pela adaptação à mudança, compensando perdas e utilizando meios compensatórios e suporte social. É similar ao explicado pelo modelo seleção, otimização e compensação (SOC) ${ }^{[40,41]}$, em que a pessoa analisa e avalia os seus recursos internos e externos face aos quais traça metas alcançáveis, maximizando o uso tanto das suas potencialidades como do que está ao seu dispor no ambiente envolvente e minimizando os efeitos dos seus défices ou incapacidades. Seleção, otimização e compensação constitui um processo estratégico sob o qual as pessoas adotam uma relação com o ambiente gerindo os seus recursos internos e externos, no 
individual, ancestral predisposition with family members ${ }^{[28,24,29,30,31]}$.

The results / consequences emphasize how the future is planned. It involves a positive attitude towards life, the successful aging positive feature minimized by Blazer [32]. This attitude can be built during the vital development, a process explained by Gestsdottir and Lerner ${ }^{[17]}$. It also promotes maturity and wisdom, giving people a chance to focus on creative potentials rather then problems and disease ${ }^{[33]}$.

Concerning the central concept clarification of the lived experience, we compare this aiming towards knowledge process with Bandura's self-efficacy theory ${ }^{[35,36]}$ and the Bandura and Schunk ${ }^{[37]}$ theory. We face a nurse-aged person interaction scenario viewing knowledge and capacitating reinforcement in order to reflect on the lived experience and, therefore, to show promoting and protecting behaviors for a successful aging.

A social cognition is revealed. Reflecting on the lived experience (by themself or by others, in the sense of clarification) is a method used by the aged person and by the nurse to assign meaning and at the same time, to structure the path leading to the demonstration of successful aging behaviors. This is quite evident in the life cycle transition phases and following adaptation to time-linked changes.

Self-efficacy, a key element of the socio-cognitive theory ${ }^{[34]}$, is essential in the process of knowledge augmentation. It results from believing in the intrinsic capabilities, in order to produce action results that each one would expect. Applying the Bandura ${ }^{[35,36]}$ and Bandura and Schunk ${ }^{[37]}$ perspective, nurses ensure the self-efficacy of their clients, that is, they encourage belief in their ability to bring forth the well-being they all want. Verbal stimuli, persuasion and support provided with any self-care success, might serve as an external reinforcement, building a sense of self-efficacy amongst the cared for persons.

According to the Glass perspective ${ }^{[38]}$ individuals seek understanding by reviewing others' experiences and this is specially noted in the participants' experienced dynamics. The search for understanding through the other's experiences in life is also explained by Meleis ${ }^{[39]}$, when the person is described in a transition process by assuming new roles. People learn to role-play by watching others performing those acquired roles, ensuring a successful transition. The aged person is in a transition process when we think of the successive adaptations associated to time ${ }^{[40,41,17,42,43,44]}$.

Thinking in the experienced world referred to by Heidegger ${ }^{[45]}$, the individual's consciousness naturally describes their experiences in life, and that is the basis of the relationship established with the world they live in sentido de experienciarem um desenvolvimento bem-sucedido ${ }^{[27]}$. A velhice é para ser vivida partilhando a terra com os outros. Há uma predisposição individual, ancestral e com os familiares $[28,24,29,30,31]$.

Os resultados/consequências salientam a forma como o futuro é projetado. Envolve uma atitude positiva face à vida, aspeto positivo do envelhecimento bem-sucedido relevado por Blazer ${ }^{[32]}$. Esta atitude pode ser construída ao longo do desenvolvimento vital, processo explicado por Gestsdottir e Lerner ${ }^{[17]}$. Igualmente promove maturidade e sabedoria, dando possibilidade às pessoas de se centrarem em potenciais criativos desfocando-se de problemas e da doença ${ }^{[33]}$.

Quanto ao conceito central: clarificação do vivido, comparamos este processo de caminhada para o conhecimento com a teoria da autoeficácia de Bandura ${ }^{[35,36]} \mathrm{e}$ Bandura e Schunk ${ }^{[37]}$. Estamos perante um cenário de interação enfermeiro-pessoa idosa que visa o aumento do conhecimento e capacitação no sentido de refletir sobre o vivido e consequentemente evidenciar comportamentos promotores e protetores de envelhecimento bem-sucedido.

Desvenda-se uma cognição social. Refletir sobre o vivido (por si ou pelos outros, no sentido de clarificação) é um método utilizado pela pessoa idosa e pelo enfermeiro para atribuir sentido e, ao mesmo tempo, para estruturarem o caminho que conduza à manifestação de comportamentos de envelhecimento bem-sucedido. É bem patente nas fases de transição do ciclo de vida e de adaptação às mudanças associadas ao tempo.

A autoeficácia, elemento-chave da teoria sociocognitiva ${ }^{[34]}$, é fundamental no processo do aumento do conhecimento. Constitui a crença nas capacidades intrínsecas, com a finalidade de produzir os resultados esperados pelas ações de cada um. Aplicando a perspetiva de Bandura ${ }^{[35,36]}$ e Bandura e Schunk ${ }^{[37]}$, os enfermeiros asseguram a autoeficácia dos seus clientes, isto é, estimulam a crença nas suas capacidades para levar por diante o desejo de bem-estar pretendido. Os estímulos verbais, a persuasão e o apoio manifestado a cada prova de sucesso no autocuidado, podem servir como reforço externo na construção de um sentimento de autoeficácia por parte das pessoas cuidadas.

$\mathrm{Na}$ perspetiva de Glass ${ }^{[38]}$ os indivíduos procuram a compreensão através da revisão das experiências dos outros e isso é notório na dinâmica vivida pelos participantes. A procura da compreensão através do vivido do outro é igualmente explicada por Meleis ${ }^{[39]}$, quando descreve a pessoa em processo de transição ao assumir novos papéis. As pessoas aprendem a desempenhar papéis vendo esse mesmo desempenho naqueles que já têm esse papel adquirido, ou seja, com uma transição bem-sucedida. E a pessoa idosa está em transição 
[46]. The way the aged person looks for meaning or tries to understand the world during their vital path, allows them to understand their own lived experience. Interaction with the world is related to the person's integration and the situation itself, as the aged person assumes this role by reflecting on the nature of their own existence. This path in the search for knowledge probably is not far from the happiness enunciated by Aristotle, or the good life explained by Ricoeur ${ }^{[47,48]}$, when referred to a successful aging process.

Thus, clarification requires the implementation of information, designed to enrich knowledge. The lived experience is understood as something that is felt and experienced by the persons. Lived experience, as clarification, emerges in an individual relationship context.

\section{Conclusion}

The Clarification of the Lived Experience became the central reason of the nurse-elderly interaction phenomenon. This is what really drives action. Being a central concept, the clarification of the lived experience interconnects with the Recreation of the Gerontologic Care and Construction of the Lived components. We realize that the Clarification of the Lived Experience emerged from all components, categories and subcategories. In the Recreation of the Gerontologic Care we have the scene players: nurse(s) and older person(s), interacting between pairs or nurse-aged person. These are all in a meeting process which triggers the action. On the other hand, the Construction of the Lived Experience refers to a whole life cycle covered by the older individual, seeking and being sought by the nurse.

We are dealing with a way in which a nurse acts, a nurse who designs and organizes an intervention in the aged person's life with the aim of contributing to the better protection and promotion behaviors of successful aging. They stand before an older individual who wants to better understand the essence of their life, the meaning of their life and gather more competences to show successful aging behaviors. Thus, the Recreation of the Gerontologic Care arises when the interaction be- quando pensamos nas sucessivas adaptações que vai efetuando face às modificações associadas à passagem do tempo ${ }^{[40,41,17,42,43,44]}$.

Se nos reportarmos ao mundo vivido explicado por Heidegger ${ }^{[45]}$, a pessoa através da sua consciência descreve naturalmente as suas experiências de vida, sendo essa a base da relação com o mundo em que se insere ${ }^{[46]}$. O modo como o idoso procura o sentido ou a compreensão do mundo ao longo do seu percurso vital, fá-lo perceber a sua própria experiência vivida. A interação com o mundo está relacionada com a integração do ator e com a situação, papel que o idoso assume ao refletir sobre a natureza da sua existência. Este caminho de procura do conhecimento não estará longe da felicidade enunciada por Aristóteles, ou de vida boa explicitada por Ricoeur ${ }^{[47,48]}$, quando se incluem num processo de envelhecimento bem-sucedido.

Deste modo, a clarificação pressupõe a transposição de uma informação refletida fomentadora de enobrecimento do conhecimento. O vivido é entendido como algo que é sentido e experienciado pelos atores. Tanto clarificação como vivido emergem num contexto de relação entre sujeitos.

\section{Conclusão}

Clarificação do Vivido passou a ser a razão central do fenómeno interação enfermeiro-pessoa idosa acontecer. É o que move toda a ação. A Clarificação do Vivido ao ocupar a posição de conceito central interliga-se às componentes Recriação do Cuidado Gerontológico e Construção do Vivido. Percebemos que a Clarificação do Vivido emergiu de todas as componentes, categorias e subcategorias copuladas. Na Recriação do Cuidado Gerontológico temos em cena os atores: enfermeiro(s) e pessoa idosa(s), interagindo entre pares ou enfermeiro-pessoa idosa. Todos estão num processo do encontro para o desencadear da ação. A Construção do Vivido por seu lado refere-se a todo um ciclo vital percorrido pela pessoa idosa a qual procura e é procurada pelo enfermeiro.

Estamos perante um modo de agir do enfermeiro, que projeta e organiza uma intervenção junto da pessoa idosa com o fim de a tornar cada vez mais capaz de evidenciar comportamentos protetores e promotores de envelhecimento bem-sucedido e perante uma pessoa idosa que quer conhecer melhor o cerne da sua vida, o sentido da sua vida, de reunir cada vez mais competências para evidenciar comportamentos de envelhecimento bem-sucedido. Por isso a Recriação do Cuidado Gerontoló- 
tween nurse and aged person Predisposes Knowledge, Favors Knowledge, Strengthens Knowledge, while the construction of the lived experience emerges when the older person aims towards integrity, establishing Social and Individual Interaction while enhancing experiences.

By the end of this study it is clear that gerontological nursing has as its focal centre the aged person and how they respond to the life process, not in an involutive biopsychosocial decay sense, but rather as an older individual perspective. The older person undertakes projects, maintains health, recognizes their empowerment and sees the advantages in aging. At the same time, the nurse working with the aged person promotes unquestionable joy when they are professional and fully dedicated, providing committed care which always promotes harmony and satisfaction.

Flood ${ }^{[10]}$ proposed the holistic care through interventions grounded in a multidimensional perspective. With the present study we add that the professional nurse might work as a facilitating agent of the human response to aging, in a search for the truth about the older person's life experiences, gathering objective knowledge that provides the expected results.

\section{Conflict of interests}

The authors declare that there are no financial or personal relations that could be viewed as a potential conflict of interests. gico surge quando enfermeiro e pessoa idosa em interação vão Predispondo o Conhecimento, Favorecendo o Conhecimento e Reforçando o Conhecimento e a Construção do Vivido, emergindo quando a pessoa idosa vai Caminhando para a Integridade, Estabelecendo Interação Individual e Social e Intensificando Vivências.

Enfermagem gerontológica, no término do nosso estudo, passou a ter claramente como objeto focal a pessoa idosa e o modo como ela responde ao seu processo de vida não no sentido involutivo e de decadência biopsicossocial, mas sim numa perspetiva de indivíduo com mais anos vividos, que detém projetos, mantém a saúde, reconhece o seu empowerment e ganhos no envelhecimento. Paralelamente exercer enfermagem junto dos mais velhos constitui um inquestionável maravilhamento quando os seus profissionais enveredam pelo cuidar numa total dedicação e disponibilidade manifestando uma evidente harmonia e satisfação.

Flood ${ }^{[10]}$ propôs o cuidado holístico através de intervenções alicerçadas numa perspetiva multidimensional. Com o presente estudo acrescentamos que o enfermeiro pode ser um agente facilitador da resposta humana da pessoa idosa ao seu processo de envelhecimento numa procura de verdade sobre a sua experiência de vida obtendo um corpus de conhecimento objetivo que o faz obter resultados esperados.

\section{Conflito de interesses}

Os autores declaram que não existem relações financeiras ou pessoais que puderam ser vistas como um potencial conflito de interesses. 


\section{References / Referências}

[1]] Corbin, J. \& Strauss, A. Basics of Qualitative Research, 3rd ed. Los Angeles: Sage, 2008.

[2] Ministry of Health Healthy Aging. Directorate General of Health 2009; http://www.app. com.pt/wp-content/uploads/2009/01/envelhecimentosaudavel.pdf

[3] United Nations Secretariat The Millennium Development Goals Repot 2009; http://www. un.org/ millenniumoals / Pdf / MDG Report_2009_ENG. pdf

[4] National Institute of Statistics Projections of the resident population in Portugal from 2008 to 2060 in 2009; http://www- ine.pt

[5] Baltes, P. \& Smith, J. New frontiers in the future of aging: From successful aging of the young old to the dilemmas of the fourth age. Geontologist 2003, 49, 123-135.

[6] Costa, A. Caring for Seniors: Training, practice and skills of enfrmeiros. Lisbon: Formasau; 2002.

[7] Moniz. J. Nursing and elderly: care practice as a formative experience. Lisbon: Lusociência; 2003

[8] Fernandes, M. Report development of $\mathrm{PhD}$ project. Lisbon: Portuguese Catholic University, 2008.

[9] Flood, M. Successful Aging: A Concept Analysis. The Journal Of Construction \& Testing Theory 2002, 6 (2), 105-108.

[10] Flood, M. The Mid-Range Nursing Theory of Successful Aging. The Journal Of Construction \& Testing Theory 2006, 9 (2), 35-39.

[11] Ferrario, C., Freeman, F., Nellet, G. \& Scheel, J. Changing nursing students' attitudes about aging paradigm. Educational Gerontology 2008; 34, 51:66

[12] Gavan, C. Successful aging families: A challenge for nurses. Holistic Nursing Practice 200317 (1), 11-18.

[13] Sikora, S. The University of Arizona College of Medicine Optimal Aging Program: Stepping in the Shadows of Successful Aging. Geriatrics \& Education Gerontology 2006, 27 (2), 59-67.

[14] Wykle, M., Whitehouse, P. \& Morris, D. Successful aging trough the life span: intergenerational issues in health. Educational Gerontology, 2007 ; 33, 463-466.

[15] Richards, L. Teach-yourself NVivo 7:the introductory tutorials 2006. http://download. Qsrinternational.com/Document/NVivo7/ NVivo7_Tutorials_Lyn_Richards.pdf

[16] Pender, N., Murdaugh, C. \& Parsons, M. Health Promotion in Nursing Practice, 6th ed. New Jersy: PrenticeHall; 2010.

[17] Tomey, A. \& Alligood, M. Theoretical Nursing and His Work (5. ${ }^{\text {a }}$ ed.). Loures: Lusociência; 2004

[18] Gestsdottir, S. \& Lerner, R. Positive Development in Adolescence: The Development and Role of Intentional Self-Regulation 2008 Human Development, 51, 202-224.
[19] Marchand, H. The age of wisdom. Port: Ambar, 2005.

[20] Fernández-Ballesteros, A., Caprara, M. \& García, L. Vivir con vitality-M ®: The european multimedia Programme. Psychologie in spain 2005, 9 (1), 1-12.

[21] Erikson, J. The Life Cycle Completed. New York: Norton, 1998.

[22] Cardoso, A.Vida and Perception Si Lisbon: Colibri, 2008.

[23] Locke, J. Essay Concerning Human Understanding. Lisbon: Calouste Gulbenkian Foundation, 1999.

[24] Tornstam, L. Gerotranscendence: The Contemplative Dimension of Aging. Journal of Aging Studies 1997, 11 (2), 143-154.

[25] Tornstam, L. Gerotranscendence from young old age to old old age. The social group Gerontology, Uppsala, 2003. http://www.soc. uu. if / fulltext / gtransoldold.pdf

[26] Wadensten, B. Introducing older people to the theory of gerotranscendence. Journal of Advanced Nursing 2005, 52 (4), 381-388.

[27] World Organization Heald. Active Ageing, A Policy Framework. The Contribution of the WHO to the Second United Nations World Assembly on Ageing, Madrid, Spain, April. http:// whqlibdoc .who.int/hq/2002/who nmh_nph_02.8.pdf

[28] Riediger, M., Baltes, P. \& Lindenberger, U. Selection, Optimization, and Compensation (SOC): Regulation of Goals and Preferences in Lifespan Development, in: Annual Report 2004 of Centerfor Lifespan Psychology, 2004.

[29] Thorsen, K. The paradoxes of gerotranscedence: The theory of gerotranscendence in a cultural gerontological and post-modernist perspective. Norweqian Journal of Epidemiology 1998; 8 (2), 165-176.

[30] Verbraak, A. Gerotranscendence: an examination of the proposed extension to Erik Erikson's theory of development Identify. Master's thesis. New Zealand: University of Canterbury, 2000.

[31] Wadensten, B. \& Carlsson, M. Theory-driven guidelines for pratical care ol older people, based on the theory of gerotranscendence. Journal of Advanced Nursing 2002, 41 (5), 462-470.

[32] Wadensten, B. Introducing older people to the theory of gerotranscendence. Journal of Advanced Nursing 2005, 52 (4), 381-388.

[33] Blazer, D. Successful Aging. Journal American Geriatric Psychiatry. 2006; January: 13 (1), 2-5.

[34] Aadlandsvik, R. Education, poetry, and the process of growing old. Educational Gerontology, 2007, 33, 665-678.
[35] Azevedo, M. Perceived self-efficacy: the motivation in social cognitive theory. University of Lisbon, Faculty of Sciences 1993; http:// www.educ.fc.ul.pt/docentes/mazeved/ materials / M\% C3\%A9 todosDeEstudo_0809/1 MotivSalaDeAul06Eficac.pdf

[36] Bandura, A. Self-Efficacy: Toward a Unifying Theory of Behavior Change. Annual Review of Behavior Therapy 1976; 99-137.

[37] Bandura, A. Self-Efficacy Mechanism in Human Agency. American Psychologist 1982, 37, 122-147.

[38] Bandura, A., \& Schunk, D. H. Cultivating Competence, Self-Efficacy and Intrinsic Interest Through Proximal Self-Motivation. Journal of Personality and Social Psychology 1981, 41, 586-598.

[39] Glass, J. Visceral Verstehen. Elctroinic Journal of Sociology 2005; http://www.sociology. org/ content/2005/tier3/ Visceral \%20 Verstehen.pdf.

[40] Meleis, A. Theorical nursing: Devlopmente and progress (4th ed.). Philadelphia: Lippincott Williams \& Wilkins, 2007.

[41] Baltes, P. Baltes, M. Psycological perspectives on successful aging. The model of selective optimization with compensation. In: Baltes, P. Baltes, M. (Eds.), Successful Aging: Perspectives from Behavioral Sciences, Cambridge University Press, 1990

[42] Baltes, P. \& Smith, J. New frontiers in the future of aging: From successful aging of the young old to the dilemmas of the fourth age. Geontologist 2003, 49, 123-135.

[43] Lindenberger, U. et al. Psychological Principles of Successful Aging Technologies: A Mini-Review. Gerontology 2008, 54, 54-68.

[44] Rohr, M. \& Lang, F. Aging Well Together - The Mini-Revew. Gerontology 2009, 55, 333-343.

[45] Smith, J., Lövdén, M., Lindenber, U., Baltes, P. B., Delius, J. \& Kunzmann, U. Berlin Aging Study (BASE): Trends and Profiles of Psychological Aging in: 2004 annual report of the Center for Lifespan Psychology, 2004.

[46] Heidegger, M. Being and Time, (27th ed.). Oxford: Blackwell 2005; http://books.google.pt/ books? S57m5gW0L id $=$ MC \& printsec $=$ frontcover $\& \mathrm{dq}=$ heidegger, + knowledge, + being + and + time $\&$ source

[47] Walters, A. The phenomenological movement: implications for nursing research. Journal of Advanced Nursing 1995, 22, 791-799.

[48] Ricoeur, P. Soi-même comme un autre. Paris: Éditions du Seuil, 1990

[49] Ng, L. Ethics: Roots and blooms in All Ways. Loures: Lusociência; 2009. 